\title{
Non-Oil Revenue and Economic Growth in Nigeria
}

\author{
Adeusi, Amos Sunday ${ }^{1} \quad$ Uniamikogbo, Emmanuel $^{1} \quad$ Erah, Ose Dominic (Ph.D $)^{2}$ \\ Aggreh Meshack (Ph.D) $)^{2}$ \\ ${ }^{1}$ Department of Accounting, Adekunle Ajasin University, Akungba-Akoko, Ondo State, Nigeria \\ ${ }^{1}$ Department of Accounting, Rhema University, Aba, Abia State, Nigeria \\ ${ }^{2}$ Central Bank of Nigeria, Federal Capital Territory, Abuja, Nigeria \\ ${ }^{2}$ Department of Accountancy, Nnamdi Azikiwe University, Awka, Anambra State, Nigeria
}

\begin{abstract}
This study examined the effect of non-oil revenue on economic growth in Nigeria. The four specific variables proxy for non-oil revenue are: Value Added Tax, Companies Income Tax, Personal Income Tax and Custom \& Excise Duties, while Gross Domestic Product was used to represent economic growth in Nigeria. The study population consists of all individuals, corporation soles and corporate organisations whose taxes were paid to the Nigerian government except firms operating in the upstream industry. The study sample consists the entire population of study using the census sampling approach. The secondary source of data collection method was used in generating data from the Federal Inland Revenue Service Statistical bulletin of 2018 and the National Bureau of Statistics of 2019 for the period 1994-2018. The descriptive statistics and Ordinary Least Square (OLS) regression techniques were used to analysed the data collected. The study findings revealed that indirect taxes (Custom \& Excise Duties and Value Added Tax) have more significant positive effect on the Nigerian economic growth than direct taxes (Companies Income Tax and Personal Income Tax). Also, direct taxes have significant but negative effect on the Nigerian economic growth, especially in the long run. It is therefore recommend that simple and transparent tax laws be enacted to regulate the tax regimes in Nigeria in order to avoid any form of illicit strategic tax behaviour by management. Also, the problems of implementation of good tax reforms policies should be eliminated. Tax authority should provide strategies to strengthen the control on the significant variables identified in this study analysis.
\end{abstract}

Keywords: Tax revenue, economic growth, gross domestic product, direct tax, indirect tax.

DOI: $10.7176 / \mathrm{RJFA} / 11-8-10$

Publication date: April $30^{\text {th }} 2020$

\section{Introduction}

The level of economic growth of any nation depends largely on the amount of revenue generated and channeled towards the development of the country. Unfortunately, the continue increase in government responsibilities and her inability to meet up with her financial challenges resulting from increasing size in population and infrastructural decay attributed to dwindling oil price and prevailing inflationary situation of the country which erodes the value of funds available to render essential social service to the people (Nimenibo, Samuel, Eyo, Mni $\&$ Friday, 2018) have forced Nigeria government to source for alternative revenue generating source. One of the sure ways of generating alternative revenue in Nigeria is tax. Okafor (2012) advocated the use of tax as a mechanism for social engineering, to stimulate general and/or sectoral economic growth.

Tax therefore, is a mandatory charge levied on a tax payer or upon his estate by the sovereign institution to generate needed revenue required for providing social amenities, security, and make available favourable conditions for the economic welfare of the people (Appah \& Oyandonghan, 2011). A fee that is charged or levied on a product, income, or activity by the government is known as tax. When the fee is directly charged on an individual or corporate entity's income, it is known as direct tax, but, where it is imposed on the prices of goods or services, then, it is titled an indirect tax. Government imposed tax on her citizens for the purposes of revenue generation to finance her expenditures, redistribution of income and wealth to reduce income inequalities, protection of weak or infant industry, regulation of macro-economy, curb inflation, and so on (Anyanfo, 1996).

Non-oil revenues are revenues generated from sources other than the oil producing activities (such as petroleum revenue from the upstream activity and other oil related operations). Examples of non-oil revenue include revenues from companies not engaged in oil \& gas explorations, such as Companies Income Tax, Personal Income Tax, Custom and Excise Duties and Value Added Tax, etc. Thus, tax imposed on these non-oil producing activities by the government is called non-oil tax, and the revenue realised by the government in the imposition of non-oil tax is known as non-oil tax revenue.

Flowing from above, it is apparent that tax aside being an income generating source to the government, it also serves as a tool for the regulation of economy. Therefore, in order for government to grow her economy using revenue from taxes, factors favourable to the taxpayers must be appropriately considered. Nzotta (2007) identified four key issues that must be considered for an efficient and effective tax role in any society. Firstly, a tax is a mandatory contribution made by the citizens to the government and this contribution is for common use. Secondly, 
a general responsibility is imposed on the tax payer through tax. Thirdly, there is an assumption that the financial input made by the tax payer to the public revenue may not be equal to the benefits derived. Finally, government imposition of tax on a citizen is not based on the fact that it has rendered particular services to the taxpayer or the family.

\section{LITERATURE REVIEW AND HYPOTHESES DEVELOPMENT}

\subsection{Conceptual Review}

\subsubsection{Concept of Tax}

ccording to World Bank (2000), taxes are mandatory relocation of incomes to the government from the rest of the economy. Any country's best system should be to take into account and decide its economic framework, its ability to manage taxes, its societal service needs, and lots of other factors. National Tax Policy (2008) defines tax as a financial obligation or charge levied on a person or corporate entity by a public authority; it is a burden laid upon individuals or property to generate revenue in funding government expenditure.

Omotoso (2001) defines tax as a mandatory levy enforced by government on the income and estates of persons and corporate enterprises as stated by government Decree, Acts or Laws regardless of the particular amount of service of the payer in return. Tax is that percentage or an amount of income that must be paid as tax to government from the income and profits of individuals and organisations. It is an obligation individual and firms must satisfy so long as they are in business. Akintoye and Tashie (2013) postulated that the willingness of citizens to pay tax is very important and cannot be ignored. They suggested that government should pay attention to the factors that influence the willingness of citizens to pay tax and improve on them.

\subsubsection{Tax Revenue}

Tax revenue is the revenue generated by government of a jurisdiction from oil and non-oil activities. Tax revenue is the receipt from tax structures. Revenues accruing to an economy like Nigeria can be categorized into two main parts: oil revenue and non-oil revenue. Ihendinihu, Ebieri, Amaps and Ibanichuka (2014) confirmed that the federal government revenue is classified into two mains sources as oil and non-oil revenue. Oil revenue to the government is revenue derived from royalties, receipts from petroleum profits tax, and local sales and exports of crude oil and gas, while the revenue from non-oil includes revenue from Levies, public debt, grants, Personal Income Tax (PIT), Custom and Excise Duties, (CED), Companies income tax (CIT), Valued Added Tax, Education Tax, aids, amongst others. A country's tax system is a major determinant of the macroeconomic indexes for developed and developing economies; hence, there exist a relationship between the tax structure and the level of economic growth of any nation (Libabatu, 2014).

\subsubsection{Economic Growth}

According to Olopade and Olopade (2010), growth means an increase in economic activities. Ayres and Warr (2006) define economic growth as a rise in the total output (goods or services) produced by a country. It indicates a rise in the capability of a country to produce goods and services, compared from one period to another. Economic growth is defined by Dwivedi (2004) as the net national product over a period of time or a persistent rise in the nation's per capita output over a long period of time. This indicates that the rate of population growth is lower than the rate of increase in total output. The increase in the value of goods and services produced within a country over a specified period of time is known as economic growth. This increase in economic growth is measured using Gross Domestic Product (GDP). So, it is likely for a country to have an economic growth that do not certainly results in economic development in the short, medium or long run (Hadjimichael, Kemeny, \& Lanahan, 2014) as economic growth does not automatically translates to economic development. In this regard, tax revenue could have a positive or negative effect on the economic growth of any nation depending on its level of management by the relevant tax authorities. Government in a bid to increase tax revenue and grow her economy should put in place measures to curtail tax revenue leakages resulting from loopholes in the tax law.

\subsubsection{Gross Domestic Product (GDP)}

According to Onuoha, Ibe, Njoku, and Onuoha (2015), Gross Domestic Product is the most detailed and widely acceptable measure of total output or performance of an economy. According to the Central Bank of Nigeria (2010), GDP is defined as the monetary value of goods and services produced within a period of time in an economy regardless of the ethnic nationality of those who produced the goods and services. Nnamocha (2002) defines Gross Domestic Product as the total money value of all goods and services produced in the domestic economy by everybody in that economy no matter where they come from provided they reside within the economy. Nnamocha (2002) further posits that GDP comprises both the citizens and non- citizens of an economy and it must be equal only to the value of the end products. Onuoha et al., (2015) state the discrepancy between Gross Domestic Product and Gross National Product by saying that while Gross Domestic Product concentrates on the county in which income is generated with emphasis on where the output is produced, Gross National Product is concerned with those who produced the income. Ruffin (1998) posits that Gross Domestic Product broadly measures the total output of the economy which includes only the final goods and services to avoid double counting of products. GDP is calculated by measuring the total income value. Nominal GDP measures the monetary value of final goods 
and services in current market prices and rises either because of increasing output or rise in the price of products. Real GDP measures the quantity of real goods and services by removing the effect of inflation in prices. However, some categories of goods and services such as illegal goods, non-market goods, and leisure value are excluded from Gross Domestic Product since GDP merely measures economic welfare to the people and not a measure of economic "bads" (Ruffin, 1998).

\subsection{Measurement of Tax Revenue}

The mechanisms considered appropriate to measure non-oil tax revenue as used in this study are: Companies' Income Tax (CIT), Personal Income Tax (PIT), Value Added Tax (VAT) and Custom and Excise Duties (CED). They are explained below:

\subsubsection{Companies' Income Tax (CIT)}

According to Okeke, Mbonu and Ndubuisi (2018), a company is defined as any company or corporation (other than corporation sole) established by or under any law in force in Nigeria or elsewhere. The institution responsible for the registration of companies in Nigeria is the Corporate Affairs Commission (CAC).

Ogbonna and Appah (2016) defines Companies Income Tax (CIT) as a tax levied on the profit of companies (excluding profit from companies engaged in upstream operations) accruing in, derived from, brought into or received in Nigeria in respect of any trade or business, rent, premium, dividends, interest, loyalties and any other source of annual profit. Hence, Ariwodola (2000) resolved that the companies' income tax is chargeable on the global profits of Nigerian companies irrespective of whether or not they are brought into or received in Nigeria. The share of the profits of foreign firms derived from such firm's operations in Nigeria (dividends, interests or royalties due to foreign companies) is assessed at ten percent $(10 \%)$ withholding tax rate. Companies Income Tax (CIT) is charged at 30 percent rate of assessable profits of companies. From the foregoing, our second hypothesis is formulated as follow:

\section{$H_{01}$ : Companies income tax has an insignificant effect on the Nigerian economic growth.}

\subsubsection{Personal Income Tax (PIT)}

Personal income refers to income of individuals, families or communities arising from employment, business, trade, profession, or vocation (Dandago \& Alabede, 2001). Personal Income Tax (PIT) (Amendment) Act 2011 defines personal income tax as the tax imposed by the government on the incomes of individuals and corporation soles. This tax is levied on individuals, body of individuals or corporation soles based on their level of income or profits.

The relevant tax authority responsible for the collection of Personal Income Tax (PIT) is the State Internal Revenue Services of the respective states and the Federal Inland Revenue Services respectively. While the State Internal Revenue Service is responsible for the collection of taxes of individuals, body of individuals or corporation soles who are deemed to be resident that year in their respective states, the Federal Inland Revenue Service collects personal income taxes of individuals, body of individuals or corporation soles resident in the Federal Capital Territory (FCT), members of the military and police, Nigerians on foreign mission, and non-resident individuals. This tax is easy to collect as it is deducted at source by the appropriate tax authority (Cislac \& Abu, 2012). However, despite its ease of collection, it has remained the most disappointing, non-performing, unsatisfactory and problematic in the history of Nigerian tax system (Kiabel \& Nwokah, 2009; Nzotta, 2007). Thus, our third hypothesis is as follows:

\section{Ho2: Personal income tax has no significant effect on economic growth in Nigeria.}

\subsubsection{Value Added Tax (VAT)}

Value Added Tax (VAT) is the tax levied on the value which the supplier or seller of goods/services add to the goods/services before selling it. The introduction of VAT was necessitated by the need to boost the revenue of the government from non-oil sources following the fluctuations in the oil revenue due to the glut in the international market. VAT was introduced into the Nigerian tax system in 1994 fiscal year with the promulgation of VAT Decree No. 102 of 1993 to replace the Sales Tax Act, 1986 at the 5\% rate and is being administered by the Federal Inland Revenue Services (PWC, 2018). Value added tax is a multiple stage tax that is charged on the additional value of goods produced or services rendered as they advance through numerous stages of production \& distribution and the rendering of services which is ultimately borne by the last consumer but collected at each phase of production and service chain (Bird, 2005). According to Umeora (2013), value added tax is a tax on estimated market value added to a product or service at every phase of manufacturing or distribution and the additions are eventually added to goods and services which bear the tax burden or the incidence because the tax paid on consumption of goods and services cannot be recovered. The value added of a firm is the difference between a firm's sales (output) and purchases (input) from other firms. The value added of a firm is the amount of value it contributes to the goods produced or services rendered using some factors of production such as land, labor, capital and entrepreneurial ability of the firm. A section of VAT Decree No. 102, 1993, specifically exempted some goods and services from tax. These goods and services are those that bother purely on people's well-being and are essentially required to advance human growth and development. The category of goods and 
services exempted from tax include, but not limited to; medical products and services, pharmaceutical products, basic food items, books and educational materials, plants and machinery for use in export processing zones (EPZs) or free trade zones (FTZs) and commissions on stock market transactions (PWC, 2018). According to the Federal Inland Revenue Service (1993), VAT is a consumption tax that is relatively easy to administer and difficult to evade and it has been embraced by many countries world-wide. On this basis, our third hypothesis is stated as follow:

$H_{03}$ : Companies income tax has no significant effect on economic growth in Nigeria.

\subsubsection{Customs and Excise Duties (CED)}

The introduction of Customs duty which is also known as import duty dates back to 1860 . In Nigeria, customs duties are the oldest form of modern tax revenue and it consists the main revenue source for the Federal Government which is payable by importers of specified goods (Buyonge 2008). Customs duty are taxes levied on goods and services imported into Nigeria, it is charged either as a percentage of the value of goods or services imports or as a fixed amount of contingent on quantity (unit tax) of goods (Buba, 2007). To further broaden the revenue base of Nigeria, excise duties were also introduced on several goods in 1962 in Nigeria (Buba, 2007). Excise duty is a tax levied on locally manufactured goods, sale, or use of locally produced goods (such as alcohol, tobacco, petrol, manufactures, and so on). Excise duties are charges imposed by government on specific commodities produced in a country at differing rates. These charges are being imposed on domestic products locally produced as distinct from imported goods and are mainly imposed for revenue generating purposes. The major difference between both taxes is while excise duty is levied by the government on the goods and products that are manufactured locally in a country, customs duty is levied on goods imported from foreign countries. Custom duties are the totality of import duties collected by the customs and excise Department. However, excise taxes are either 'selective or general' or 'specific or ad valorem' depending on the tax base.

Customs and excise duties are an essential element of the non-oil revenue and have remained the major revenue source before and after the discovering of oil in Nigeria and have over the years contributed significantly to national development. According to Buba (2007), the Nigeria Custom Services is saddled with the responsibility of collecting customs and excise duties, fees, tariffs, and other levies so imposed by the Federal Government on imports, exports and statutory rates. So our last hypothesis is translated as follows:

H04: Customs and excise duties have no significant effect on economic growth in Nigeria.

\subsection{Review of Theories}

\subsubsection{Socio-Political Theory}

Government role in terms of economic growth of a nation is generally portrayed through their policy choice (monetary and fiscal policies). Socio-political stability is imperative for economic progress, thus, in a multicultural country like Nigeria policies might not be always economic. Therefore, the government should ensure that the populace stands "unity in diversity".

This study is anchored on the "Socio Political Theory" propounded by Adolph Wagner in 1835. The German political economist Adolph Wagner (1835-1917), after experimental examination on Western Europe at the end of the 19th century developed a "law of increasing state activity" and was named after him as Wagner's Law. In his view, he said that increased industrialisation and economic development precede government growth. Thus, government growth is a function of industrial growth and economic development. According to Wagner, as the real income per capita of a nation increases, the share of public expenditures in total expenditures increases during the process of industrialisation. "The arrival of modern industrial society as cited by the law will result in growing political pressure for social progress and increased allowance for social consideration by industry."

The Social Political Theory advocated by Adolph Wagner articulates that social and political objectives should be the deciding factors in selecting taxes. Bhartia (2009) posits that the Social Political Theory encouraged that a tax system should be designed to cure the ills of society as a whole, and should not be used to serve individuals as expected. Wagner, an advocate of social political theory does not believe in individualist approach to a problem but, rather, economic problem should be looked at from its social and political context and an appropriate solution proffered thereof.

Pressures from economic, social and political groups to protect and promote its interest as well as administrative inability to efficiently collect taxes at a reasonable cost have forced authorities to reshape tax structure to accommodate these pressures. Chigbu, Akujuobi and Appah (2012) are of the view that the tax system should be directed towards the health of the society as a whole, since individuals are essential part of the wider society and the society is made up of individuals more than the sum total of its individual members. Tax revenue provides a potent set of policy tools to the governments which should be efficiently used for correcting economic and social problems of the people such as income disparities, regional differences, cyclical fluctuations unemployment, and so on. The socio-political theory of taxation looks at how tax affects the economy as a whole as against individuals. Therefore, decision taken at any particular time should be based on what the government considers to be of necessity and beneficial to the society. This theory is associated with the normal development 
process and represents a standard against which we can compare the country's particular empirical evidence.

\subsection{Review of Empirical Studies}

Okun and Micah (2018) examined the effects of tax revenue on Nigeria economic growth. Time series data were sourced from Central Bank of Nigeria statistical bulletin and Federal Inland Revenue service from 1980 to 2016. Real Gross Domestic Product was modeled as the function of percentage of companies' income tax, personal income tax and custom and excise duties tax. Granger causality test and Johansen co-integration test in the vector error correction model (VECM) setting were employed. Durbin Watson, $\beta$ Coefficient, R-Square (R2) and FStatistics were used to determine the relationship between the dependent and independent variables as formulated in the regression models. The result proved that petroleum profit tax, companies' income tax and personal income tax revenue have negative relationship with Nigeria economic growth while custom and excise duties tax have positive effect on Nigeria economic growth. The regression results showed that tax revenue have significant relationship with Nigeria economic growth.

Khadijat and Taophic (2018) evaluated the effect of Petroleum Profit Tax and Company Income Tax on Nigerian economy growth. They applied the Fully Modified Least Square (FMOLS) Regression Technique to estimate the model over a 34 years period (1981-2014) using the Augmented Dickey Fuller Unit Root Test and Single Equation Co-integration Test. Findings revealed that Petroleum Profit Tax (PPT) and Company Income Tax (CIT) both have positive and significant impact on gross domestic product (GDP) in Nigeria. The study resolved that PPT and CIT serves as the main source of revenue to the Nigeria economy, and contribute to the growth of Nigeria economy.

Nimenibo et al (2018) empirically examined tax revenue and economic growth in Nigeria from 1980 to 2015 , employing Gross Domestic Product (GDP) as the dependent variable and Petroleum Profit Tax (PPT), Company Income Tax (CIT), and Customs and Excise Duties (CED) as the independent variables. The study was conducted using the Multiple Regression Analysis employing the Ordinary Least Square (OLS) method of econometrics as the analytical technique. The regression result showed that there is no significant relationship between Petroleum Profit Tax, Company Income Tax, Custom and Excise Duties and economic growth in Nigeria.

Manukaji (2018) investigated the effect of tax structure on economic growth in Nigeria. The study made use of time series data from 1994 to 2016. Tax was disaggregated into value added tax, Company Income Tax, Petroleum Profit Tax, and Personal Income Tax. These tax components were regressed against Gross Domestic Product which is a proxy for economic growth. The data generated were analyzed using descriptive statistics, stationarity test, cointegration test and ordinary least square. The study found that all the tax components studied (Value Added Tax Revenue, Personal Income Tax Revenue, Petroleum Profit Tax Revenue and Company Income Tax Revenue) has significant influence on economic growth in Nigeria.

Fave and Dabari (2017) examined tax revenue collection by the Federal government in Nigeria. The quantitative research design was adopted using the secondary data obtained from FIRS for the total tax revenue collected from the oil and non-oil taxes for the period of 2011-2015. The Federal Inland Revenue Services constitutes the population of the study. The sample size of the study was drawn from the Planning, Reporting and Statistics Departments of the Federal Inland Revenue Services. The study findings revealed that Capital Gains Tax, Stamp Duty, Education Tax and Petroleum Profit Tax are positive and significant while Company Income Tax and Value Added Tax are not significant. However, of all the remaining variables, Company Income Tax has more total collected revenue.

Okwara and Amori (2017) examined the impact of tax revenue on the economic growth in Nigeria. They considered a 22year period covering 1994-2015. Data sourced from secondary documents such as journals, textbooks and Central Bank of Nigeria (CBN) statistical bulletin were used for the study analysis. Variables considered were Gross Domestic Product (GDP) proxy for economic growth, Value Added Tax (VAT), and nonoil income (tax). The Ordinary Least Square (OLS) regression with the aids of Statistical Package for Social Sciences (SPSS) was used to test the significant impact of value added tax and non-oil income on Gross Domestic Product (GDP) to avoid spurious results. The results revealed that non-oil income has significant impact on gross domestic product while value added tax has negative relationship and statistically insignificant for the period under review. The study concludes that tax revenue have significant impact on Nigerian economy growth.

Popoola, Jimoh, and Oladipo (2017) investigated tax revenue and Nigerian economic growth for period of three decades, using time series data from 1986 to 2015. Data were collected from the Central Bank of Nigeria (CBN) Statistical Bulletin and National Bureau of Statistics (NBS).The study utilised both descriptive and Paired Sample T-test with the aid of Statistical Package for Social Science (SPSS) Version 23. The findings showed that, oil and non-oil tax revenue were positive and strongly correlated with Real Gross Domestic Product (RGDP).

Ojong, Anthony and Arikpo (2016) studied the impact of tax revenue on the Nigerian economy. The desk survey method was used to extract data sourced from the Central Bank Statistical Bulletin. The Ordinary Least Square of multiple regression models was employed to establish the connection between dependent and independent variables. Findings revealed that there is a significant relationship between Petroleum Profit Tax, non- 
oil revenue, and Nigerian economic growth. Findings also revealed that there is insignificant relationship between Companies Income Tax and Nigerian economy growth.

Arowoshegbe, Uniamikogbo and Aigienohuwa (2016) examined tax revenue and economic growth of Nigeria. The specific objective of the study was to explore the influence of income tax revenue on the Nigerian economic growth proxied by Gross Domestic Product (GDP). Data for the period 1995 to 2015 were respectively collected from the Statistical Bulletins of Federal Inland Revenue Service and the Central Bank of Nigeria. The study adopted the Econometric Model of Multiple Linear Regressions and Ordinary Least Square (OLS) technique to explore the correlation between GDP (the dependent variable) and a set of government income tax revenue heads for 11 years period. Findings from the study showed that tax revenues that determine government economic growth are Petroleum Profit Tax and Company Income Tax. This indicates that taxes that have positive effect on economic growth are direct taxes, thus direct taxes wield more significant effect on Nigerian economic growth than indirect taxes.

\section{METHODLOGY}

This study adopted the ex-post facto research design. This design method was chosen because data used in this study were sourced from secondary materials and not manipulated. The secondary source of data collection method was used to generate data from the Federal Inland Revenue Service (FIRS) statistical bulletin of 2018 and the National Bureau of Statistics (NBS) bulletin of 2019 for the period 1994 to 2018. The population of study consists of all companies quoted on the Nigeria Stock Exchange (NSE), corporation soles, and individuals who pay taxes to the government except companies in the upstream operations (Petroleum companies). The sample size comprises the entire population of study for a period of Twenty-five years (1994-2018) using the census sampling approach. The entire population was selected as the sample size of the study with a view to reaching a robust and valid judgement for generalisation. Data generated from the FIRS and National Bureau of Statistics (NBS) bulletins respectively were analysed using the econometric model of multiple linear regressions and the use of Ordinary Least Squares (OLS) technique.

According to Koutsoyiannis (1977), economic theory does not specify the functional form of any association whether in linear, quadratic or in a cubic form. On the strength of the above, and given the dynamic nature of the panel data that was used in this study and in line with Minnick and Noga (2010) as cited by Salawu and Adedeji (2017), this study imposed a linear relationship between economic growth and the explanatory variables which are tax revenues features that potentially explain variation in Gross Domestic Product. Relationship was established between GDP and Companies' Income Tax (CIT), Personal Income Tax (PIT), Value Added Tax (VAT) and Custom and Excise Duties (CED. Using a linear regression of Gross Domestic Product on the exogenous variable described above, the model is expressed functionally as:

$\mathrm{RGDPG}=f(\mathrm{CIT}, \mathrm{PIT}, \mathrm{CED}, \mathrm{VAT})$

The econometric model is expressed thus:

$\mathrm{RGDPG}=\mathrm{b}_{0}+\mathrm{b}_{1} \mathrm{CIT}+\mathrm{b}_{2} \mathrm{PIT}+\mathrm{b}_{3} \mathrm{CED}+\mathrm{b}_{4} \mathrm{VAT}+e t$

Where;

RGDPG $=$ Growth rate of Gross Domestic Product (proxy for economic growth)

CIT $=$ Companies Income Tax

$\mathrm{PIT}=$ Personal Income Tax

$\mathrm{CED}=$ Custom and Excise Duties

$\mathrm{VAT}=$ Value Added Tax

$\mathrm{b}_{0}=$ Constant

$b_{1}, b_{2}, b_{3}, b_{4}=$ coefficients

et $=$ Error term

Equation (3.2) represents the baseline equation that captures the main tax dimensions in Nigeria. However, in formal models of economic growth (such as Harold-Domar and Solow-Swan), there are critical factors that determine growth over time. These factors are the labour and capital contributions to growth. Exclusion of these factors from growth estimation, especially in a developing country, can lead to omitted variable problem in the econometric models (Iyoha, 2004). In order to avoid the problem of omitted variables, Equation (3.2) is respecified to include both capital (k) and labour (l). Capital is measured as the grossed fixed capital formation, while labour is measured as the secondary school enrolment rate. Both variables are expected to exert positive impacts on real GDP growth at any period. The model is therefore specified as:

$\mathrm{RGDPG}=\mathrm{b}_{0}+\mathrm{b}_{1} \mathrm{CIT}+\mathrm{b}_{2} \mathrm{PIT}+\mathrm{b}_{3} \mathrm{CED}+\mathrm{b}_{4} \mathrm{VAT}+\mathrm{b}_{5} \mathrm{~K}+\mathrm{b}_{6} \mathrm{~L}+$ et

Where; $\mathrm{K}=$ capital accumulation

$\mathrm{L}=$ labour input

In apriori terms, taxes that are more indirect (CED and VAT) are expected to have positive impacts on economic growth, while the direct taxes (CIT and PIT) are expected to have negative impact on growth since they directly constitute leakages in the macroeconomic system. 
The Equations in the specified models do not fully capture the tax structures in Nigeria. Hence, in order to further show the dimensions of tax compositions in Nigeria, a further Equation is specified to use both direct and indirect taxation in the system. The model is specified as:

$$
\begin{aligned}
& R G D P G=a_{0}+a_{1} D T A X+a_{2} I N D T A X+U_{t} \\
& \text { Where DTAX }=\text { share of direct taxes in total GDP } \\
& \text { INDTAX }=\text { share of indirect taxes in total GDP }
\end{aligned}
$$

In order to obtain the objectives of this study, the co-integration and error correction modeling (ECM) technique was used for the estimation of the relationships specified in the models. Four processes are involved in this technique; unit root testing, co-integration analysis, the dynamic short run model and the long run estimation.

\section{DATA PRESENTATION AND ANALYSIS \\ 4.1 Descriptive Statistics}

Annualised summary of the main series used in this study are reported in Table 1 in terms of descriptive statistics. The Table shows that average GDP growth rate for the entire period was 2.85 , which is relatively low. However, the maximum and minimum figures suggest that the growth rate in the economy have been widely diverse since 1994, with a minimum rate of -1.75 and a maximum rate of 7.57. The period of weak growth was experienced in the 1990s, when commodity prices where low and there was poor management of the domestic system. In terms of the tax structure, the Table shows that the share of indirect taxes in GDP was larger than that of direct taxes over the period on average. Thus, indirect tax revenues appear to be more than revenues obtained from direct taxes in Nigeria. Among the taxes represented in the study, average value of CIT is much higher than any of the other taxes. This shows that companies' income taxes (as expected) are the main tax contributions in Nigeria over the years. On the other hand, PIT has the least average tax value among the tax components. This is to be expected since figures are based on FIRS which compute only Federal Government-based taxes. The share of capital appears to be greater than that of labour in the system.

Table 1

Descriptive Statistics

\begin{tabular}{ccccccccc}
\hline & Mean & Max. & Min. & Std. Dev. & Skewness & Kurtosis & J-B & Prob. \\
\hline GDPGR & 2.851 & 7.571 & -1.752 & 2.494 & -0.105 & 2.188 & 0.703 & 0.70 \\
INDTAX & 3.376 & 5.670 & 0.819 & 1.479 & 0.033 & 1.687 & 1.729 & 0.42 \\
DTAX & 2.120 & 3.043 & 0.251 & 0.574 & -1.294 & 5.735 & 14.177 & 0.00 \\
CED & 356.51 & 1012.87 & 23.697 & 306.03 & 0.865 & 2.461 & 3.284 & 0.19 \\
CIT & 485.17 & 1409.21 & 13.400 & 479.25 & 0.597 & 1.789 & 2.893 & 0.24 \\
PIT & 196.63 & 677.36 & 23.952 & 167.16 & 1.171 & 3.858 & 6.225 & 0.04 \\
VAT & 391.59 & 1108.04 & 9.479 & 356.35 & 0.479 & 1.788 & 2.385 & 0.30 \\
H & 45.130 & 54.820 & 33.380 & 7.156 & -0.140 & 1.649 & 1.904 & 0.39 \\
K & 81.594 & 154.200 & 6.330 & 53.374 & 0.051 & 1.343 & 2.756 & 0.25 \\
\hline
\end{tabular}

Source: Author's computations

The standard deviation values for each of the variables are sufficiently low and show that the data series are well-distributed, as is also shown by the low skewness values for each of the variables. A special statistic of interest in this study is the Jarque Berra (J-B) coefficients in the summary statistics. It shows the degree of normality, and hence the heterogeneity of the data series. Highly heterogeneous series are ineffective for ECM estimations. The $\mathrm{J}$-B values for each of the variables in the models are low and insignificant, apart from the direct tax which is significant at the 1 percent level. This indicates that the assumption of normality in the data is accepted: the series are all mostly normally distributed are therefore suitable for the ECM estimation.

\subsection{The Error Correction Mechanism (ECM) (Short-Run Analysis)}

The short-run dynamics of the behavior of economic growth in the context of short term movements in taxation as well as the other variables in Nigeria is captured within an error correction model (ECM). The autoregressive distributed lags (ARDL) approach is used for the ECM. The error correction representations for the selected ARDL model are presented in Table 2. The R-Bar squared criterion was used for the selection of the parsimonious equation. 
Table 2

The Short-run Dynamic Model for Economic Growth Participation

\begin{tabular}{c|ccc|ccc}
\hline Variable & Coeff. & t-Statistic & Prob. & Coeff. & t-Statistic & Prob. \\
\hline Constant & -0.058 & -2.81 & 0.015 & -0.030 & -1.87 & 0.080 \\
$\Delta L C I T$ & 0.019 & 2.18 & 0.048 & -- & -- & -- \\
$\Delta L P I T$ & -0.040 & -2.77 & 0.016 & -- & -- & -- \\
$\Delta L V A T$ & -0.013 & -0.47 & 0.648 & -- & -- & -- \\
$\Delta L C E D$ & -0.007 & -0.24 & 0.812 & -- & -- & -- \\
$\Delta$ SINTAX & -- & -- & -- & 0.001 & 0.13 & 0.898 \\
$\Delta S D T A X$ & -- & -- & -- & 0.010 & 1.25 & 0.231 \\
ALH & 4.107 & 6.32 & 0.000 & 2.436 & 4.03 & 0.001 \\
ALK & 0.006 & 0.62 & 0.547 & 0.016 & 1.30 & 0.212 \\
ECM & -0.501 & -1.52 & 0.153 & -0.227 & -0.67 & 0.512 \\
\hline R-squared & 0.802 & & & 0.683 & & \\
Adj. R-squared & 0.650 & & & 0.545 & & \\
F-statistic & 5.27 & & & 4.93 & & \\
D.W. stat. & 1.78 & & & 1.78 & & \\
\hline
\end{tabular}

Source: Author's computations

The error correction mechanism results for the disaggregated model as well as those of the aggregated model (with direct and indirect taxes) are reported. Both equations report quite impressive diagnostic outcomes, although the disaggregated model has higher values. The R-squared value of 0.802 for the disaggregated results indicates that over 80 percent of the systematic variation in growth of the economy at any given time is explained by the explanatory variables and the ECM term. Less than 20 percent of such variation is stochastic. For the aggregated results, the adjusted R-squared value of 0.683 indicates that about 68 percent of the variation in economic growth was captured with the tax compositions.

In the same direction, the F-statistic value of 5.27 and 4.93 for the disaggregated and aggregated equations respectively are high and both easily pass the significance test even at the 5 percent level, since these values are both greater than the critical F-value of 4.01. Thus, we accept the hypothesis of a significant log-linear relationship between economic growth and all the independent variables put together in the short run. In other words, the tax variables seem to have a significant relationship with the performance of the economy at any given time.

The relevance or specific roles of each individual explanatory variable is considered by examining the coefficients of each respective variable in terms of its signs and significance. A close investigation of the individual coefficients of the variables in the disaggregated model reveals that only the coefficient of CIT and PIT are significant at the 5 percent level. This is because the $t$-value of each of the coefficient is greater than the 5 percent critical t-value of 2.20 (in absolute value). Moreover, the probability values of each of the coefficient are less than the 0.05 level. This underscores the fact that company income tax and personal income tax are the critical tax components that determine temporary movements in the performance of the Nigerian economy at any given time. All the other coefficients of the tax variables (including CED and VAT) failed the significance test at the 5 percent level. This suggests that these tax components do not have significant impacts on economic growth in the short run.

The coefficient of CIT is positive, while that of PIT is negative. This indicates that in the short run, company income taxes (in terms of revenues from it) tend to boost economic growth in Nigeria. On the other hand, personal income taxes actually effectively reduce the performance of the economy, perhaps due to its capacity to discourage effort and reduce the personal spending capacities of individual income earners in Nigeria.

For the aggregated equation, the coefficients of the two tax components variables fail the significance tests at the 5 percent level. This shows that aggregate tax composition in Nigeria does not effectively promote growth in the economy. Rather, it is the focus on individual tax patterns that exert significant short-term effects on growth. In the two sets of estimations, the coefficient of human capital was significant at the 1 percent level, while that of capital fails the test. This shows that human input is essential for promoting economic growth in the short run in 
Nigeria.

The coefficient of the error correction term has the correct negative sign which shows that equilibrium can be attained after any form of short run disequilibrium in the system. The coefficients for the ECM term two equations however failed the significance test even at the 5 percent level. This indicates that disequilibrium may persist for a long term before it may be restored. The DW statistic value of 1.78 is generally impressive and shows absence of autocorrelation in the models. Thus, for structural analysis and policy directions, the short-run estimates in the model above are reliable.

\subsection{The Long Run Relationships}

The ordinary least squares estimate of the long run equations are presented in Table 3 . The results show that most of the models explained over 97 percent of the behaviour of the respective independent variables. Moreover, the overall goodness of fit of each of the models is also impressive. The F-statistic is significant at the 1 percent level for all the equations, the computed values are greater than the 1 percent critical value of 4.01 , thereby establishing the assertion of a significant long run relationship between macroeconomic variables and the direct tax measures.

Table 3

\section{Long Run Results}

\begin{tabular}{c|ccc|ccc}
\hline Variable & Coefficient & t-Statistic & Prob. & Coefficient & t-Statistic & Prob. \\
\hline Constant & -1.484 & -1.31 & 0.21 & 3.550 & 13.17 & 0.00 \\
LCIT & 0.062 & 2.02 & 0.06 & -- & -- & -- \\
LPIT & -0.050 & -2.04 & 0.06 & -- & -- & -- \\
LVAT & -0.045 & -1.11 & 0.28 & -- & -- & -- \\
LCED & -0.163 & -3.25 & 0.00 & -- & -- & -- \\
SDTAX & -- & -- & -- & -0.001 & -0.11 & 0.92 \\
SINDTAX & -- & -- & -- & 0.036 & 1.75 & 0.10 \\
LH & 2.964 & 7.94 & 0.00 & 1.208 & 15.82 & 0.00 \\
LK & -0.022 & -1.09 & 0.29 & 0.046 & 3.34 & 0.00 \\
\hline R-squared & 0.988 & & & 0.975 & & \\
Adj. R-squared & 0.983 & & & 0.969 & & \\
F-statistic & 199.8 & & & & & \\
\hline
\end{tabular}

Source: Author's computations

The examination of the individual coefficients of the explanatory variables show that in the overall macroeconomic model, the coefficient of CED manages to pass the significance test at the 1 percent level, while that of CIT and PIT passed the test at the 10 percent level. Only VAT failed the significance test even at the 10 percent level. This shows that VAT has no significant impact on economic growth in Nigeria, both in the short run and in the long run. Among the significant tax coefficients, only that of CIT was positive, while all the others were negative. This shows that only company income taxes tend to promote economic growth in Nigeria. All the direct taxes in the model demonstrated negative coefficients which suggest that direct taxation actually reduce growth in Nigeria. Again, both the direct and indirect tax structures in the result in the second panel of the Table 4.3 failed the significance test. Thus, it does not actually pay to consider taxation in aggregate terms in Nigeria for the purpose of determining the effect of taxes on economic growth.

\subsection{Discussion of Findings}

From the empirical analysis of the study, there are certain issues that call for more discussion in terms of the outcomes. First, the study has demonstrated that in evaluating the relationships between non-oil tax revenue and economic growth in Nigeria, a disaggregated approach, where all the non-oil taxes are considered presents better results than an aggregative approach. This result is similar to findings by Okwara and Awori (2016), Onakoya and Afintinni (2016) and Ogundana et al (2017) who also showed that using particular taxes in Nigeria reveals greater linkages with growth in the system. This outcome is particularly important since it highlights the importance of focusing on tax revenues in particular. It also shows that there is need to set up strong institutional settings that tend to critically examine tax components more stringently in order to note the growth-enhancing patterns (Adegboye, Alao-Owunna \& Egharevba, 2018). This shows that aggregate tax compositions in Nigeria do not 
effectively promote growth in the economy. Rather, it is the focus on individual tax patterns that exert significant short term effects on growth.

The study has shown that both in the long run and short run, taxation on production or company income taxes (CIT) has positive and significant impacts on economic growth in Nigeria. This result also strongly corroborates other studies. For instance, Ojong, Anthony and Arikpo (2016) also showed the effectiveness of production taxes in the economy. Indeed, taxation on production affect the location of business, alter the ways in which production takes place, changes the form in which business. Perhaps the importance of this tax structure rests on the fact that production tax is easy to administer and less expensive to collect.

Tax issues constitute strong consideration for businesses in Nigeria, especially in the era of increased drive for more revenue by government. There is often a dilemma for the government in terms of allowing small businesses to grow and develop and the collection of taxes. Reducing the compliance burden of small business taxpayers may necessitate reducing complexity of the different tax laws or introducing the types of simplification measures discussed above. It also relates to ensuring that more formal regulations, such as the procedures regarding filing, record keeping requirements, procedures for appeal or payment delays, are not unnecessarily complex. An effective tax system for small businesses is a scheme that thoroughly brings together policy, legislation, compliance strategies and taxpayer services. Such a system is most probable to decrease compliance problems for these businesses; stimulate their compliance and reduce costs of tax administration.

The negative impact of direct taxation on economic growth is clear since it has strong inhibition to performance by workers (Adegboye et al., 2018). Taxes influence the sharing of income before-tax by altering economic incentives and also influence the after tax allocation of income through progressive income taxation. Though, tax policy design primarily should be guided by key criteria such as equity, efficiency, and administrative feasibility for an effective tax system design.

\subsection{CONCLUSION AND RECOMMENDATIONS \\ 5.1 Conclusion}

The mobilization of tax revenue is an important policy objective. Governments in the short run can do little or nothing to alter structural determinants of the tax revenue (such as composition of value added), however, they have the powers to change other factors which are internal to her that influence tax revenue, such as economic policies, the level of corruption, and the quality of tax administration. The wide divergence between the effective and statutory tax rates in Nigeria indicates that there is scope for raising tax revenue without increasing tax rates by enforcing tax and customs administrations, reducing tax exemptions (especially in the areas of manufacturing), and fighting fraud and corruption. Nevertheless, one must be realistic in terms of improvement in revenue ratios that can be reasonably expected to be achieved in Nigeria, given the low level of development and the heavily agricultural and informed character of the economy. Indeed, optimizing tax mobilisation and carrying out reforms can be achieved only when there is a strong political will and leadership to adopt the necessary measures. Overall, it is shown from the study that tax revenues lead to effect on economic growth. The study findings revealed that:

i. Indirect taxes have more significant positive effects on the Nigerian economy than direct taxation. Only one tax component in the study (i.e., CIT) had a positive coefficient in the study. This implies that indirect taxes, which seem to exert a more general impact on individuals, in a country actually stimulate the rate of economic activities in the country.

ii. Direct taxes have significant negative effects on the Nigerian economic growth, especially in the long run. Thus, taxes which have more personal implications tend to yield debilitating effects on economic growth impact. This suggests that efficiency of direct tax management is much lesser than that of indirect tax management in Nigeria.

iii. The level of tax administration tends to generate instability in the economic system in Nigeria. The result was seen from the insignificant coefficient of the ECM term in the models.

iv. The results showed that a proper mix of direct and indirect taxes in Nigeria will result in highly productive tax regimes that would ensure long run economic improvements.

\subsection{Recommendations}

Following the study findings, recommendations for policy are outlined as follows:

i. The efficiency of the Nigerian tax system should be improved on by combining royalties and profitsensitive taxes with close attention to details and implementation.

ii. The perceived links between paying tax and enjoying the benefits of public spending should be strengthened. Increasing awareness of this relationship can clearly be constructive for the economy as a whole.

iii. Simple and transparent tax laws should be enacted to regulate the tax regimes in Nigeria with a view to eliminating the problems of implementation of good tax reforms policies.

iv. The tax base in Nigeria should be as broad as possible since this can minimise tax distortions and revenue 
losses. In particular, attention should be carefully given to taxes on production since the study shows that only CIT has positive impacts on economic growth in Nigeria.

v. Frequent changes made in the tax structure by relevant tax authorities by way of tax policy should either be avoided or minimised, since it increases enforcement, compliance and efficiency costs, thus affecting production and business decisions.

\section{REFERENCES}

Abdul-Rahamoh, O. A., Taiwo, F. H., \& Adejare, A. T. (2018). The analysis of the effect of petroleum profit tax on Nigerian economy.

Adegboye, A.C., Alao-owunna, I. \& Egharevba, M.I. (2018). Business characteristics, tax administration and tax compliance by SMEs in Nigeria. Oradea Journal of Business and Economics, 3(S1), 7-17.

Adereti, S.A., Sanni, M. R., \& Adesina, J. A. (2011). Value added tax and economic growth of Nigeria. European Journal of Humanities and Social Sciences, 10 (1).

Akintoye, I. R \& Tashie, G. A. (2013). The effect of tax compliance on economic growth and development in Nigeria, West -Africa. British Journal of Arts and Social Sciences, 11(2), 222-231. Retrieved from http://www.bjournal.co.uk/BJASS.aspx.

Anyanfo, A.M. (1996). Public finance in developing economy: The Nigerian case. Department of Banking and Finance, University of Nigeria, Enugu Campus. Enugu.

Appah, E., \& Oyandonghan, J. (2011). The challenges of tax mobilization and management in the Nigerian economy. Journal of Business Administration Management, 6(2):128 - 136.

Arowoshegbe, O. A., Uniamikogbo E., \& Aigienohuwa O. O. (2016). Tax revenue and economic growth of Nigeria. Scholars Journal of Economics, Business and Management, 4(10), 696-702.

Bhartia, H.L. (2009). Public finance. New Delhi: Vikas Publishing House PVT Ltd.

Bird R. M. (2005) Value added taxes in developing and transitional countries: Georgia State Working paper No. 05 .

Buba, J. G. (2007). The role of the customs reforms in boosting non-oil revenue in Nigeria. University of Jos, Nigeria Symposium.

Buyonge, C. (2008). Organisational design of customs in Sub-Sahara Africa: A critical evaluation. World Customs Journal.

Central Bank of Nigeria, (2017). Central Bank of Nigeria statistical bulletin.

Chigbu, E. E., Akujuobi, L. E., \& Appah, E. (2012). An empirical study on the causality between economic growth and taxation in Nigeria. Current Research Journal of Economic Theory, 4 (2), 29-38.

Cislac, \& Abu, M. M. (2012). Power to change institution. Retrieved from https://www.christianaid.org.uk/sites/default/files/2019-11/Power-to-change-institutions-report-NigeriaJuly-2019.pdf

Dandago, K. I., \& Alabade, J. O. (2000) Taxation and tax administration in Nigeria. Kano Triumph Publishing Company Ltd.

Dwivedi, D. N. (2004). Management Economics 6th Ed: London Matins Press Inc.

Fave, K. S., \& Dabari, I.J. (2017). Empirical analysis of tax revenue collection by the federal government in Nigeria. European Journal of Accounting, Auditing and Finance Research, University of Technology, Yola, $5(2), 1-11$.

Federal Inland Revenue Service (1993). Information Circular No. 93

Hadjimichael, F.M., Kemeny T \& Lanahan L. (2014). Economic development: A definition and model for investment. Available from http://www.edu.gov/tool.

Ihendinihu, J.U, Ebieri J., Amaps \& Ibanichuka, E. (2014): Assessment of the long-run equilibrium relationship between tax revenue and economic growth in Nigeria: 1986 to 2012. The SIJ Transactions on Industrial, Financial \& Business Management (IFBM), 2(2), 39-47.

Khadijat, A. Y., \& Taophic, O. B. (2018). Effect of petroleum profit tax and companies income tax on economic growth in Nigeria. Journal of Public Administration, Finance and Law, 13.

Kiabel B. D., \& Nwokah N. G. (2009) Boosting revenue generation by state governments in Nigeria: The tax consultants option revisited. European Journal of Social Sciences, 8 (4).

Koutsoyiannis, A. (1977). Theory of Econometric. HumpshireMacmillian Education Ltd. London. Macmillan.

Lababatu, S. G. (2014). Tax revenue and economic growth in Nigeria. M.Sc. Thesis submitted to department of Accountancy, Faculty of Administration, Ahmadu Bello University, Zaria.

Manukaji, I., J. (2018).Effect of tax structure on economic growth in Nigeria. International Journal of Innovative Finance and Economics Research,Federal Polytechnic,Bida, 6(1), 1-11.

Minnick, K., \& Noga, T. (2010). “Do corporate governance characteristics influence tax rate?” Journal of Accounting Literature. 16, 1-27.

National Tax Policy. (2008). National tax policy: handbook by Federal Ministry of Finance. 
Nimenibo, A., Samuel, W. A., Eyo, M. J., Mni \& Friday, H.C. (2018). An empirical analysis of tax revenue and economic growth in Nigeria from 1980 to 2015. Global Journal of Human-Social Science: Political Science, $18(3)$.

Nimenibo, A., Samuel, W. A., Eyo, M. J., Mni \& Friday, H.C. (2018). An empirical analysis of tax revenue and economic growth in Nigeria from 1980 to 2015. Global Journal of Human-Social Science: Political Science, $18(3)$.

Nzotta, S. M. (2007). Tax evasion problems in Nigeria: A critique Nigeria account. Journal of Management Accounting Research, 40(2), 40- 43.

Ogbonna, G. N. (2009). Burning issues and challenges of the Nigerian tax systems with analytical emphasis on petroleum profits tax. International Journal of Accounting, Finance, \& Economics Perspectives, 1(1), 17 34.

Ogbonna, G. N., \& Appah, E. (2016). Effect of tax administration and revenue on economic growth in Nigeria. Research Journal of Finance and Accounting, 7(13), 49 - 58.

Ogundana, O.M., Ogundana, O.M., Ogundana, O.M.. Ibidunni, A.S. \& Adetoyin, A. (2017). Impact of direct and indirect tax on the Nigerian economic growth. Binus Business Review, 8(3), 215-220.

Ojong, C. M., Ogar, A, \&Arikpo, O. F. (2016). The impact of tax revenue on economic growth: Evidence from Nigeria. IOSR Journal of Economics and Finance, University of Calabar, Calabar, 7 (1), 32 - 38.

Ojong, C.M, Anthony, O. \& Arikpo, O.F. (2016). The impact of tax revenue on economic growth: Evidence from Nigeria. IOSR Journal of Economics and Finance, 7(1), PP 32-38.

Okafor, R. G. (2012) Tax Revenue Generation and Nigerian Economic Development, European Journal of Business and Management, 4, (19).

Okeke, M. N., Mbonu, C. M., \& Ndubuisi, A. N. (2018). Tax revenue and economic development in Nigeria: A disaggregated analysis. International Journal of Academic Research in Accounting, Finance and Management Sciences, 8 (2), 178 - 199.

Okun, I. P. and Micah, L. C. (2018). Tax revenue and economic growth in Nigeria (1980-2016). Ceka International Journal of Finance \& Management Sciences, 4 (2).

Okwara, C. C., \& Amori, O. M. (2017). Impact of tax revenue on economic growth in Nigeria. International Journal of Scientific Research in Social Sciences \& Management Studies, Federal Polytechnic Ilaro, 2(2).

Okwara, C.C. \& Amori, O.M. (2016). Impact of tax revenue on economic growth in Nigeria. International Journal of Advanced Scientific Research, 2(2), 90-102.

Olopade B.C \& Olapade. D.O (2010). The impact of growth and development in developing countries: Nigeria as a case study 4(3), 121-130.

Omotoso, M. 0. (2001): Principles of taxation. ( $1^{\text {st }}$ Ed.). Ibadan: DFirst shepherd investment.

Onakoya, A.B. \& Afintinni, O.I. (2016). Taxation and economic growth in Nigeria. Asian Journal of Economic Modelling, 4(4), 199-210.

Onuoha, D. O., Ibe, A., Njoku, C. U., \& Onuoha, J, I. (2015). Analysis of the gross domestic product (G.D.P) of Nigeria: 1960-2012. West African Journal of Industrial \& Academic Research, 14 (1).

Popoola, A. A., Jimoh, I., \& Oladipo, A. A. (2017). Tax revenue and Nigerian economic growth. European Journal of Accounting, Auditing and Finance Research, College of Technology, Esa-oke, 5(11), 75-85.

PWC. (2018, December 19). Nigeria corporate-other taxes. Retrieved May 15, 2019, from PWC: http://taxsummaries.pwc.com/ID/Nigeria-Corporate-Other-taxes.

World Bank. (2000). East Asia: Recovery and beyond. Washington, D.C.: The World Bank. 